\title{
Islamic Organisation and Electoral Politics: Nahdlatul Ulama and Islamic Mobilisation in an Indonesian Local Election $^{1}$
}

\section{Luthfi Makhasin}

Received: 4 August 2017 | Accepted: 8 December 2017 | Published: 18 December 2017

\begin{abstract}
This paper deals with the politics of patronage and piety in local elections by examining the role of and dilemma faced by Nahdlatul Ulama (NU), the largest Muslim organisation in Indonesia, in a local electoral competition. Focusing on the 2017 local election in Brebes, Central Java, this article confirms previous scholarly works' findings of widespread patronage distribution and the impact of rising religious conservatism on electoral competition. However, this paper shows that piety and patronage politics neither necessarily maintain oligarchic rule nor provoke intolerance and violence. The case of the electoral competition in Brebes reveals that Islamic organisations in Indonesia are not immune from electoral politics, and due to institutional weaknesses of most political parties in Indonesia, will likely remain important political players by mobilising support in elections at both the local and national level. In a broader context, Islamic mobilisation in local elections in Indonesia helps understand the emergence of pious democracy in democratic Muslim-majority countries.
\end{abstract}

Keyword: patronage; piety; local election; incumbent; Nahdlatul Ulama; Islamic mobilisation.

\section{Introduction}

Since the beginning of Reformasi, politics in Indonesiathe largest Muslim democracy in the world-has been unable to escape several enduring paradoxes. These paradoxes are reflected, for example, in the continued practice of oligarchy and predatory activities in democracy and the free market (Robison and Hadiz, 2004; Hadiz and Robison, 2013), the continued use of consociational

\footnotetext{
1 The author would like to thank PolGov, Universitas Gadjah Mada, and the Coral Bell School of Asia Pacific Affairs, Australia National University, which fully funded the data collection and writing of this article.
} 
power-sharing mechanisms between ideologically opposed social and political (Sebastian, 2004), the institutional weakness of political parties in the competitive multi-party system (Buehler and Tan, 2007; Choi, 2004, 2007), the widespread fragmentation emerging from the dominant patronage politics and neoliberal economy (Aspinall, 2013a), the focus on ethnic and religious identities amidst the weakening of formal political associations (Aspinall, Dettman, \& Warburton, 2011; Ufen, 2008), and increased piety amidst the commodification of Islam in the public sector (Fealy and White, 2008).

Since the implementation of decentralisation at the end of the 1990s and direct elections in 2005, the pendulum of politics has swung to regional governments. Hundreds of new autonomous regions have been established, and thousands of regional elections have been held at the provincial and regency/city level. Because of their significance at the local and national level, local politics (in general) and direct regional elections (in particular) have become a seemingly bottomless well of materials and arenas for researching the paradoxical patterns and tendencies of contemporary Indonesian politics (Aspinall and Fealy, 2003; Erb and Sulistiyanto, 2009).

The broad range of academic studies into local politics and elections tend to follow three theoretical approaches that reflect dominant points of view in contemporary Indonesian politics: political economy, patron-client relations, and institutionalism. The first approach focuses on the alliances that attempt to maintain specific groups' dominance in the possession of resources and power (Hadiz and Robison, 2013; Winters, 2013). In this approach, the collapse of State authoritarianism and the liberalisation of the market is seen as facilitating long-time rulers as they adapt themselves to and hijack the democratic system to maintain their economic and political dominance. This approach produces theses related to oligarchic power and predatory political interests.

Unlike the political economy approach, the patron-client approach assumes that reciprocal (give and take) relations exist 
within agrarian societies. In this approach, electoral politics is understood as an arena where the voluntary exchange of money or goods (or both) are considered a conventional means of gaining access to power (Vel, 2005; Aspinall and Sukmajati, 2016). Meanwhile, the third approach focuses on the presence and roles of democratic institutions such as political parties, the media, etc. This third approach tends to highlight the institutional shortcomings of political parties and their implications for the management and accountability of public policy (Tan, 2006; Buehler and Tan, 2007; Buehler, 2007; Choi, 2004, 2007).

Although these three dominant approaches all have their own advantages, they are incapable of fully explaining the complexities and paradoxes of contemporary Indonesian politics, including the diverse viewpoints used by political scientists to understand the expression of religion (and, more specifically, Islam) in electoral competitions in Indonesia. Some have argued that, given the erosion of faith-based politics, religion is no longer determinant in-or at least has limited influence on-voters' preferences in Indonesia (Liddle and Mujani, 2007, p.851). However, not a few academics have argued that political Islam has played and continues to play an important role in shaping voters' political orientations (Baswedan, 2004; Tanuwidjaja, 2010).

Basing itself on previous studies about local politics and regional elections, this article attempts to re-examine the diverse academic arguments regarding regional elections in Indonesia as related to the political mobilisation of Islam. This offers an alternative means of understanding political practices, one that does not simply position economic resources and political interests as determining political power in Indonesia (Ford and Pepinsky, 2013, p. 2). Although they have become inseparable parts of the local political dynamics in Indonesia, the author argues that oligarchy/ patronage cannot be taken for granted as the most valid means of explaining contemporary Indonesian politics. At a certain level, electoral contestations also involve the contestation of non-material 
symbols.

This article focuses on religion's use as a symbol of cultural and political authority amidst the increased dominance of the oligarchy and the weakening of Islamic political parties since Reformasi. It is intended predominantly to explain that the political involvement of Islam at a specific local level and in a specific local context can limit (but not eliminate) the material resource-based political mobilisation that has become widespread in contemporary Indonesia. This article is also hoped to provide a more nuanced understanding of the politicisation of religion in electoral contestations and competitions in Indonesia, as well as to identify a different approach to using communal/primordial identities in elections in post-Reformasi Indonesia.

This article focuses on the question of how the political mobilisation of Islam has adapted to the mushrooming of patronage politics, and how patronage politics has taken a role in the political mobilisation of Islam, particularly in religious identitybased electoral contestations in Indonesia. It argues that religious authority has become a unique means of articulating political patronage, one that positions cultural fidelity as an alternative to widespread political pragmatism.

The selection of Brebes was not without deliberation. This regency was selected for this research based on its historical background as well as the interesting sociological, economic, and political characteristics, which may offer a potential explanation of the transformation of political Islam in Indonesia (Hadiz and Teik, 2011; Hadiz, 2012). Brebes is one of the largest and most densely populated regencies in Central Java. Located in western Central Java, on the border of West Java, Brebes covers an area of $1,902 \mathrm{~km}^{2}$ and has a population of $1,773,739$, with an annual growth rate (in 2014) of 0.29 per cent/year. Its residents are spread through 297 villages/ sub-districts in seventeen districts. The agrarian sector, particularly seasonal produce, is the primary motor of Brebes' economy. More than sixty per cent of residents earn their income from agriculture. 
In 2015, Brebes only had a gross regional product of 252 milliards. ${ }^{2}$ Furthermore, the majority of residents of Central Java are members of Nahdlatul Ulama (NU), and the majority of residents of Brebes are nahdliyyin, persons who identify themselves as members of the organisation.

The decision to focus on the role of NU in regional elections was also based on the fact that little English-language scholarship has examined the topic, and those studies that do examine the role of NU in local politics have tended to be general in nature, failing to consider the topic in detail. On the other hand, many studies have examined the role of another Islamic organisation, Muhammadiyah, in the local politics of Indonesia since Reformasi (Jung, 2014). This is quite surprising, given the academic recognition of NU's central role in representing mainstream Islam and pro-democratic forces in Indonesia.

To support its arguments, this article is divided into five sections. The introduction explains the position of this article in relation to other studies of local politics and elections in Indonesia. This section also explains the reason for selecting Brebes as the research location as well as the rationale for focusing on the role of NU in regional elections. The second section explains the role of NU in Indonesian politics in general, as well as in Brebes in particular. The two following sections provide detailed discussion of the regional elections in Brebes as well as the role of NU in mobilising support. The fifth section draws conclusions regarding the lessons that can be learned from the regional elections in Brebes, linking these lessons to broader questions of religious identitybased mobilisation, oligarchy, and patronage politics in Indonesian elections, as well as identifying their relevance to comparative studies of Islam and democracy in Muslim-majority countries.

This data is taken from Cilacap dalam Angka 2015 and Brebes dalam Angka 2015, Statistics Indonesia. 
Data for this article were collected through field research, observation, and in-depth interviews conducted between midDecember 2016 and February 2017. Research was conducted during the campaign period, including candidate debates and media coverage. Data collection also involved meeting with and interviewing members of the election committee, regional monitoring committee, party-level political administration, campaign teams, and volunteers. Data collection was conducted in Brebes, the capital of Brebes Regency in Central Java.

\section{Local Elections and Islamic Mobilisation}

Mobilisation and popular agency have become inseparable parts of contemporary Indonesian politics (Aspinall, 2013b). Religion-based political mobilisation in Brebes, particularly the involvement of Islamic organisations in electoral contestations, is not unique, but reflects broader developments in the role of Islamic organisations in local politics in Indonesia (Jung, 2014; Fealy and Bush, 2014). Comparing the political role of NU before and after Reformasi, Fealy and Bush (2014) saw two mutually opposed tendencies: a weakening of the political authority of the kyai (Islamic teachers) even as they are increasingly involved as power brokers at the local level. Although this view has an empirical basis, it seems to reflect the once-common view of the kyai as cultural brokers in Indonesia (Geertz, 1960).

Political mobilisation in modern Indonesian democracy cannot be explained solely with a focus on charismatic actors or individuals. This is also true for explaining the political mobilisation of Islam used by NU in Indonesian electoral contestations since Reformasi. Although political mobilisation does involve the authority of the kyai, positioning such authority as the sole motive for political mobilisation is inadequate oversimplification. As with other Islamic organisations, NU has complex organisational networks, and as such religion-based political mobilisation must be understood as 
the result of complex interactions between kyai, organisational capacities, resources, and open political spaces created following the collapse of Indonesian authoritarianism. The mobilisation of piety can also not be reduced to the ideological aspirations of Islamic organisations, but must be seen as a sociological projection that positions Islam as a value system and symbolic capital that inspires political contestation.

\section{Islamic Politics in Post-Soeharto Indonesia: Contextualising Nahdlatul Ulama and Local Politics in Brebes}

The development of political Islam, specifically theinvolvement of NU in local politics, cannot be separated from the dynamics of Indonesian national politics. Islam, for the majority of Indonesia's population, is not simply a religion, but a source of collective cultural identity. Furthermore, it is a political force that has helped determine the direction of national political and institutionalisation processes. The role of Islam in politics is inseparable from the historical context of the colonial and post-colonial state, local social contexts in which Islam and Islamic practices have developed, the diverse religious and ideological orientations, as well as the generally decentralised institutional structures that are spread amongst various figures and organisations.

NU has long represented mainstream political Islam in Indonesia. Since it was established in 1926, its social and religious mission of the organisation has been to preserve the orthodoxy and traditions of Indonesian Islam. Owing to this mission, NU has long been opposed by other Islamic organisations and political parties, which have been oriented towards religious reform and sociocultural modernisation of Indonesia. Up through the early 1950s, for example, NU was one of the strongest supporters of the Masyumi Party, which represented the shared interests of various Islamic organisations that had existed before independence. NU separated itself from Masyumi and established its own political party in 1952 
owing to its ideological, religious, and political differences with its modernist allies. NU's decision to separate itself from Masyumi contributed to shaping its later political attitudes, which have been flexible and even seemingly opportunistic (Bush, 2009). However, owing to NU's strong basis at the grassroots level, it has not been able to avoid ruling regimes' efforts to co-opt it (Feillard, 2009).

The accommodation of NU in the ruling regime in the 1950s and 1960s, for example, made it possible for NU to transform itself into a source of patronage by exploiting its control over important government posts (Fealy, 2009). When Masyumi was dissolved when several of its elites were accused of involvement in regional rebellions, NU de facto became the sole representative of political Islam under Soekarno, and as the government became increasingly leftist, NU reaffirmed its position as a force for balance. Together with the Armed Forces and the Partai Komunis Indonesia (Communist Party of Indonesia, PKI), NU served as a pillar of power for Soekarno's government. Many observers have held that the organisation's good relations with Soekarno were founded on its flexibility, its ability to adapt itself to new situations, and its willingness to grant religious and symbolic legitimacy to Soekarno.

Despite providing full support to the political structure established by Soekarno, NU indirectly contributed significantly to the fall of Soekarno's guided democracy. Following the failed coup d'état of 1965, several elements of the organisation were actively involved in the military-led campaign of violence against communist forces. It involvement was, however, ultimately unable to save NU from the repression of political parties under the military-backed Soekarno regime. Although following the 1971 general election it emerged as the second strongest political force in Indonesia, NU was forced to merge into the Partai Persatuan Pembangunan (United Development Party, PPP), a political party designed as the sole representative of Islamic groups in the New Order regime.

The factional tensions within PPP, as well as the external pressures from the New Order regime, forced NU to take the drastic 
step of abandoning politics to focus on religious and social activities. During its 1984 congress, NU asserted that it would return to its founding principles, cease its formal support for PPP, and accept Pancasila as its sole basis. The good relations with those in power and the ruling Partai Golongan Karya (Working Groups Party, Golkar) that NU formed following the 1984 congress transformed following the 1994 congress in Cipasung. The organisation became increasingly critical of Soeharto and his New Order Regime. It became a symbol of civil resistance towards the regime's active coopting of pro-democracy movements (Ramage, 1995). Abdurrahman Wahid, for example, strongly rejected the establishment of the Ikatan Cendekiawan Muslim Indonesia (Indonesian Association of Muslim Intellectuals, ICMI), which he considered an extension of the ruling regime intended to accommodate Muslim actors that stood against democracy and diversity.

Wahid's reputation as the leader of NU, as well as Islamic parties' unwillingness to accept a female president, helped him gain the presidency following the 1999 presidential election. Drawing on the support of Golkar and the centrist Islamic parties organised by Amin Rais, Wahid became the first elected president of the Reformasi era. Although he was ultimately forced to resign in mid-2001 by his previous supporters, including his centrist allies, the military, and Golkar, Wahid remains the most prominent manifestation of NU's important role in Indonesian national politics since the fall of the New Order.

However, owing to the highly-decentralised structure of NU, as well as the local and personal charismatic leadership of the kyai, its role in politics has not reflected its mass support. Since NU was first established, fragmentation within its leadership structure has considerably affected its involvement in national and local politics (Laode, 1996). The tensions between the Cipete group, which remained affiliated with the PPP, and the Situbondo group, which desired to withdraw organisational support for the party, is but one example of how internal fragmentation has affected the role of NU 
in national politics. Such internal fragmentation is reflected at lower levels, and in the Reformasi era the political views and orientations held by the kyai have become increasingly diverse. Abdurrahman Wahid being replaced as the leader of the Syuro Council of the Partai Kebangkitan Bangsa (National Awakening Party, PKB) in the lead-up to the 2009 election is a concrete example of how NU has been vulnerable to internal fragmentation.

It is important to understand the national dynamics of political Islam to understand the political role of NU at the local level. This historical and socio-political context has strongly influenced how NU has become involved in local politics in Brebes. Historically, Brebes was among the areas affected by the political mobilisation of Muslims against the state's legitimate authority. In the 1950s, Brebes was one of the major strongholds of the Darul Islam/Tentara Islam Indonesia (House of Islam/Islamic Armed Forces of Indonesia, DI/TII). The movement's leader in Central Java, Amir Fatah, made his base in Bantarkawung, a district in southern Brebes. ${ }^{3}$

After Amir Fatah's rebellion was crushed in the late 1950s, political Islam in Brebes became polarised into two different ideological poles, represented by Masyumi and NU. Owing to this polarisation, Islam was unable to become a dominant political power in the region. Other, ideologically different groups enjoyed political control following the 1955 elections. With this historical background, Brebes represents an extreme point in Islamic political activism in Indonesia, the traces of which remain tangible in the local political dynamics of the region.

During the New Order, state repression of communism and radical Islamism, combined with successful economic development and an increased focus on education, brought significant social and cultural changes to Brebes. One of these was broad Islamicisation

Amir Fatah of Kroya, Cilacap, was leader of the DI/TII troops in Bantarkawung, Brebes, and the commander of the DI/TII forces in Central Java before they surrendered to the Republic of Indonesia. 
reaching all parts of the community. This is indicated by the rapid growth of Islamic education institutions, particularly pesantren (Islamic boarding schools), in the regency. Although this cannot be considered the sole indication of the power of NU in Brebes, it must be noted that the pesantren remain a means for the organisation to establish social networks. Of the more than two-hundred pesantren in Brebes Regency, Al Hikmah is the largest.

Table 1: Muslim Education/Worship Facilities

\begin{tabular}{|l|c|}
\hline \multicolumn{1}{|c|}{ Education/Worship Facility } & Brebes \\
\hline Pesantren & 201 \\
\hline Madrasa & 314 \\
\hline Mosque & 1,218 \\
\hline Musalla & 5,348 \\
\hline
\end{tabular}

Source: Compiled from data by Statistics Indonesia 2016

Aside from the pesantren, the influence of NU in Brebes has also been created through its networks of tarekat teachers. Many schools of Islamic thought, including Syadziliyah, Tijaniyah, Syattariyah, and Naqshbandi-Qodiriyah, have found broad networks in the regency. Together with Cirebon and Madura, Brebes is one of the main places where the Tijaniyah School has spread in Indonesia. The Darussalam pesantren in Jatibarang was established by Syekh Ali Basalamah (1899-1979), who introduced the Tijaniyah School to Brebes and taught many of its teachers. Tens of thousands of the faithful come to Brebes from nearby regencies such as Tegal, Pemalang, and Pekalongan for regional celebrations. Many of the school's leaders hold positions within NU and PKB. As elsewhere, strong emotional bonds are established between teachers and students; as such, tarekat networks are an important source of political power for NU (Turmudi, 2007).

The beginning of Reformasi in 1998 brought significant changes to the local political structure of Brebes, including the rise of new political forces and the weakening of old ones. The Partai 
Demokrat Indonesia-Perjuangan (Democratic Party of IndonesiaStruggle, PDIP) became a major political player, replacing the once dominant Golkar. Although the nationalist/secular group is the largest political force in the area, the situation remains quite fragmented, with different interest groups attempting to share power. This tendency for fragmentation and power sharing has made NU, which was marginalised during the New Order, into a considerable political force in local politics.

Table 2: Map of Political Power and Electoral Results in Brebes

\begin{tabular}{|l|c|c|c|c|}
\hline \multirow{2}{*}{\multicolumn{1}{|c|}{ Political Party $^{1}$}} & \multicolumn{4}{c|}{ Election } \\
\cline { 2 - 5 } & $\mathbf{1 9 9 9}$ & $\mathbf{2 0 0 4}$ & $\mathbf{2 0 0 9}$ & $\mathbf{2 0 1 4}$ \\
\hline PDIP & 17 & 13 & 13 & 11 \\
\hline P. Golkar & 5 & 7 & 7 & 7 \\
\hline PKB & 11 & 11 & 7 & 8 \\
\hline PAN & 3 & 5 & 4 & 5 \\
\hline PPP & 3 & 6 & 4 & 3 \\
\hline PKS & 1 & 3 & 5 & 6 \\
\hline P. Demokrat & & & 6 & 4 \\
\hline P. Gerindra & & & 2 & 5 \\
\hline Hanura & & & 1 & 1 \\
\hline Other & & & 1 & \\
\hline Total Seats & 40 & 45 & 50 & 50 \\
\hline
\end{tabular}

Source: General Elections Committee

Table 2 shows the number of seats in regional parliament won by the political parties in Brebes between 1999 and 2014. Although this is not able to fully and accurately represent the role of NU in local politics, the number of parliamentary seats won by different parties is able to roughly depict the organisation's rise as a political force. Two parties with strong historical ties and bases within the organisation (PKB and $\mathrm{PPP}$ ) have consistently represented a major political bloc within local parliament. In Brebes, these two parties have together held an average of $20 \%$ of parliamentary seats since 1999. In the 1999 and 2004 elections, PKB - the formal political representative of NU-even won eleven seats in regional parliament, becoming the second largest party in the region. 
Aside from the pesantren and tarekat networks, the charismatic leadership of Abdurrahman Wahid was central to gathering support for the $\mathrm{PKB}$, a party established by several kyai shortly after the beginning of Reformasi. The decreased support for PKB following the 2009 election coincided with Wahid's replacement as leader of the party's Syuro Council. The share of votes received would be higher if Golkar were included; following the 1984 congress, the party was a frequent choice for members of NU and was willing to accommodate the organisation's cadres in its administrative and leadership structure.

NU's role in the local politics of Brebes since Reformasi has been shaped through private connections as well as crossparty networks. The current head of the regional branch of NU, Athoillah Syatori, who has served since 2003, works for the Regional Government of Brebes. ${ }^{4}$ Because of his position within the bureaucracy, Syatori has served as a broker to ensure that NU has access to economic resources through the regional budget. NU has also established cross-party social networks, not only among Islamic parties such as PKB and PPP but also among secular parties such as PDIP and Golkar. The current head of the PDIP's regional council, and former regent, Indra Kusuma, is also a member of the local NU leadership for the 2013-2018 term. The head of the Golkar faction at the regional representative's council, Teguh Wahid Turmudi, was previously an administrator with GP Anshor, a youth organisation affiliated with NU. Although these cross-party networks cannot always be exploited for NU's organisational interests, personal networks such as these allow the organisation to retain access to resources and power at the local level.

The political activism of NU, which is centred on the bureaucracy and political parties in Brebes, has had consequences for the political mobilisation of Islam in the lead-up to and during 
regional elections. In Brebes, the leadership and organisational structure of NU has been relatively solid, although it has not always been capable of effectively mobilising political support. When agreements exist to support an incumbent, some elements act on their own, without any shared chain of command. Furthermore, as shown in the 2017 regional election in Brebes, the involvement and mobilisation of NU in support of specific candidates is not received the same by all members, something that reflects the diverse political contexts involved.

\section{Piety Triumph, Patronage Politics: NU, Islamic Mobilisation, and Local Election}

The 2017 regional election in Brebes was contested by two pairs of candidates. The incumbent regent and deputy regent, Idza Priyanti-Nardjo, were backed by a coalition of PDIP, Golkar, Demokrat, PPP, PAN, PKB, Hanura, and Nasdem. Their opponents, Suswono and Ahmad Mustaqim, were backed by a coalition consisting of PKS and Gerindra. In the mobilisation of support using religious issues, NU played an active role. The increased focus on religious considerations, as well as the weakening of money politics, can be attributed to shifts in the incumbents' economic resources, political manoeuvres to secure their position, and leadership capacity.

Table 3: Candidates and Coalitions in the 2017 Brebes Regional Election

\begin{tabular}{|l|l|l|}
\hline Coalition & \multicolumn{1}{|c|}{ Candidates } & \multicolumn{1}{|c|}{ Supporting Parties } \\
\hline & & PDIP (11 seats) \\
& & Golkar (7 seats) \\
& & P. Demokrat $(4$ seats $)$ \\
Victory & Idza Priyanti \& Nardjo & PPP (3 seats) \\
& & PAN (5 seats) \\
& & PKB (8 seats) \\
& & Hanura (1 seat) \\
\hline
\end{tabular}




\begin{tabular}{|c|c|l|}
\hline Coalition & \multicolumn{1}{|c|}{ Candidates } & \multicolumn{1}{|c|}{ Supporting Parties } \\
\hline \multirow{2}{*}{ Defeat } & $\begin{array}{c}\text { Suswono \& Ahmad } \\
\text { Mustaqim }\end{array}$ & $\begin{array}{l}\text { PKS (6 seats) } \\
\text { Gerindra (5 seats) }\end{array}$ \\
\hline
\end{tabular}

The shifts in the economic resources of the incumbents cannot be separated from the erosion of the "Dewi Sri" dynasty that had supported them. When direct elections were initiated in 2005, Hajjah Ruqayyah, the mother of Priyanti and owner of the inter-provincial bus company Dewi Sri, was able to position three of her children as mayors or regents along the northern coast of Central Java. Aside from Priyanti in Brebes, the "Dewi Sri" dynasty also included the election of Ikmal Jaya, Priyanti's eldest brother, as mayor of Tegal (2008-2013); and Mukti Agung Wibowo, Priyanti's younger brother, as Regent of Pemalang (2010-2015). After the youngest brother, Mohammad Edi Utomo, lost the 2013 Regional Election in Tegal, the "Dewi Sri" political dynasty along the northern coast of Central Java suffered a series of setbacks that limited its economic resources. Jaya lost the 2013 Municipal Election in Tegal, and faced accusations of corruption. In 2015, Wibowo lost the 2015 Regional Election in Pemalang. Because of these losses, as well as the corruption case, the "Dewi Sri" dynasty could no longer provide the incumbents with sufficient funding for political contestation.

The costly political manoeuvres and strategies used by Priyanti in her re-election campaign also contributed to the weakening of patronage in the 2017 regional election. According to several informants, initially the incumbents and their campaign team were certain that the candidates would emerge victorious in the election (personal communication with Muammar Riza Pahlevi, 14 January 2017). They began planning their political strategies and manoeuvres at the March 2015 PDIP regional caucus. In this, Priyanti ran as one candidate for Regional Chair, competing against the incumbent, Indra Kusuma, and the Deputy Regent, Nardjo. 
Although she ultimately capitulated, and Kusuma was voted into a third term as Regional Chair, Priyanti's willingness to run against him changed their relationship. Kusuma was unwilling to ignore the political manoeuvrings of the regent he had once backed, and thus attempted to prevent Priyanti from again running for regent with PDIP backing by instead backing Nardjo and his son-in-law, Ahmad Saefudin. Kusuma viewed Priyanti as an outsider, rather than a cadre worthy of support, unlike Nardjo, who had long been a party member and received the party's trust.

Kusuma's promotion of Nardjo and Ahmad Saefudin failed when Nardjo refused to run. According to many in the party, Nardjo refused the nomination because he lacked the necessary material resources. Although Nardjo's refusal weakened his relations with Kusuma, his political mentor, these relations improved after Nardjo gave Priyanti the space to run together with Ahmad Saefudin as the PDIP-backed candidates. This compromise, however, failed, for two reasons: Saefudin was asked to back down because he lacked the support of PDIP members, and Priyanti refused to run with him. Owing to the PDIP's internal dynamics following the regional caucus and in the lead-up to the elections, Priyanti did not fully trust the political machine, which remained wholly under Kusuma's control.

Nonetheless, the incumbent's ambition to become the sole candidate had not disappeared fully by mid-2016. The internal fragmentation of the Brebes chapter of Golkar is considered inseparable from this ambition. In Golkar's regional meeting in late July 2016, it was split into two contesting groups: those supporting Agung Widyantoro and those supporting Teguh Wahid Turmudi. The competition between these two groups resulted in a deadlock, as a result of which the meeting was relocated to Golkar's provincial office in Semarang. According to young activists in Brebes, the deadlock was rooted in the support of the party youth wing, under the command of Pamor Wicaksono-a young politician and member of the Brebes Parliament-, for Turmudi. This political 
pressure ultimately forced Widyantoro to withdraw from his planned candidacy, thereby opening a path for Turmudi to become the leader of Golkar's delegation to the Regional Representative Council for 2016-2021 (Teguh Wahid Turmudi Pimpin Golkar Brebes, 2016). ${ }^{5}$ According to some, Widyantoro's withdrawal was highly advantageous to Priyanti, as he was considered the candidate with the greatest potential to challenge the incumbent in the 2017 election. Interestingly, both Turmudi and his running mate Pamor Wicaksono had been known as faithful supporters of Priyanti since 2012.

Meanwhile, Priyanti's attempt to approach NU can be understood as integral to the incumbent's attempt to secure her position as the sole candidate, particularly given that, in the 2012 election, the organisation appeared to occupy a position opposite to them. This is shown, for example, in the demotion of Athoillah Syatori, the head of the NU branch in Brebes, within the Brebes Government. ${ }^{6}$ Among NU, this was viewed as a political consequence of his electoral defeat when he partnered with Agung Widyantoro. This changed drastically in early 2016, when Priyanti began to embrace NU, restoring her good relations with the organisation. These restored good relations are reflected, for example, in Syatori's promotion to Assistant, Governance Branch, at the Regional Secretariat of Brebes Regency. As such, Syatori, in his capacity as a prominent official in the Brebes regional government, became a bridge between the incumbent and NU, as well as a means of mobilising political support in the lead-up to the election.

Aside from the promotion of Athoillah Syatori to high political office in the Brebes regional government, NU's decision to back the incumbent can be attributed to the collective "us vs. them" identity

http://www.panturanews.com/index.php/panturanews/cetakberita/14028.

6 Between 2012 and 2016, Athoillah Syatori was demoted, ultimately occupying a position suited to his rank when he was made Third Assistant, Governance Office, at the Regional Secretariat of Brebes Regency in September 2016. 
created and reinforced in the lead-up to and during the election. This was triggered by the PKS and Gerindra's decision to back its cadres in the election. PKS backed Suswono (a PKS cadre and former Minister of Agriculture, serving 2009-2014), while Gerindra backed Ahmad Mustaqim (the head of its Brebes branch and a local leader with Muhammadiyah). The backing of these two figures touched one of the most sensitive aspects of NU's collective identity. For some in the organisation's local branch, PKS and Muhammadiyah represented two Islamic forces that were unfriendly to their religious traditions, and as such could not be expected to accommodate the political aspirations of NU.

In many ways, the decision of $\mathrm{NU}$ and its component organisations to support the incumbents in the 2017 regional election was more emotional than logical/rational. Many of the influential NU kyai in Brebes had a positive view of incumbent regent Idza Priyanti, citing her humility. Priyanti was reported to be willing to join prayer groups (pengajian) backed by the NU, until their conclusion, without demanding the strict protocol expected for officials. Among the kyai, this was considered a form of tawadu' (deference).

Priyanti's lack of leadership capacity also contributed to her inability to direct her campaign team and set her campaign agendas. She was seen as weak, owing to her inability to control her family's interference in policymaking and everyday governance. Hajjah Ruqayyah, her mother and the owner of PO Dewi Sri, was known as "Ibu Besar" (The Godmother) because of her influence on the selection of Brebes' officeholders. Rumours also spread among society of her husband's role in determining the regional budget for development projects. In this situation, for NU the decision to back the incumbent was rooted in the ancient doctrine of prioritising the avoidance of wickedness (mudhorot) over making good (maslahat). In this context, although the incumbent lacked leadership competence, the NU held that she was better than a regent/deputy regent from its political rivals (PKS and Muhammadiyah). 
Furthermore, the coalition established between PKS and Gerindra in the time before registration closed, triggered a clear shift in PKB's politics. Although the party had wanted to back an NU member, (personal communication with Abdullah Fakih Maskumambang, Secretary of the Syuro Council, Brebes Branch of PKB, 18 January 2017) as a result of the candidacy of Suswono and Ahmad Mustakim the party-as well as NU-decided to support the incumbent. The incumbent regent was considered more accommodating of NU's interests than her opponent would be. The Brebes branch of NU and PKB worked side by side to mobilise their political machines to support the incumbent, even issuing an open letter regarding this to all district- and village-level administrators.

This letter, complete with the official seal of NU, was signed by $\mathrm{KH}$ Aminudin Masyhudi and $\mathrm{KH}$ Shofiulloh Muhlas. To support the incumbents' campaign, the Brebes branch of NU also established the "Tim Nusantara Pasti Idjo" (The Team for Ensuring a Green Archipelago). Aside from NU's central leadership, Priyanti was backed by the organisation's youth organisations for men and women (GP Anshor and Fatayat). Of course, this political support was not entirely free, and may be argued to have stemmed from the funding it received from the regional budget. The Brebes branch of NU was reported to have received 250 million rupiah in financial support from the regional social assistance budget; a further 10 million rupiah was allocated for each village-level administrator (personal communication with Ahmad Munsip Maksudi, 18 January 2017).

The support of Anshor could likewise not be separated from the funding it received from the Brebes regional government. In 2015, for example, Anshor received 100 million rupiah from the regional budget for its "Anshor Bersholawat". That same year, all of Anshor's district-level administrators received 20 million rupiah in financial support from the regional budget, with a further 8 million rupiah received by all of Anshor's village-level administrators (personal communication with Ahmad Munsip Maksudi, idem). 
Most prominent in volunteer work was the Satkorcab Banser, under its leader Muhammad Ikhwan. This organisation was suspected of, and reported to the monitoring committee as, distributing 25 thousand rupiah to potential voters (personal communication with Wakro, 4 January 2017), targeting 100 people/village, 10 villages per district (a total of 17,000 people/170 villages in Brebes). ${ }^{7}$ This was but a small fraction of 3 milliard rupiah promised by Hajjah Ruqayyah (personal communication with Ahmad Munsip Maksudi, Head of the Brebes Branch of GP Anshor, 18 January 2017). Aside from distributing money, Banser was also involved in securing Priyanti's campaign team and accompanied her during her campaign activities. ${ }^{8}$

Another element that actively supported Priyanti's campaign was Fatayat, NU's women's youth group. Fatayat's support for the incumbent was not surprising, given the good relations between the organisation's regional chair, Mu'minah Tammi, and Priyanti. In the 2012 regional election, when almost all elements of NU supported Agung Widyantoro and Athoillah Syatori, Fatayat-under Tammi's leadership — backed Priyanti and Nardjo, as the former was perceived as a Fatayat member worthy of support. ${ }^{9}$ Some, however, held that Fatayat's support for Priyanti was rooted in material considerations. From 2015, every village-level chapter received 10 million rupiah from the regional budget. Priyanti also allocated 1.6 milliard rupiah for the construction of the Fatayat Multipurpose Building.

After this was discovered by the Monitoring Committee, the funding commitment was only partially fulfilled, for fear that several members of the administration would be implicated in electoral fraud.

8 The active involvement of Banser in Idza's campaign team was the subject of eternal debate, as it was considered more reflective of M. Ikhwan's personal interests than those of the organisation. The Brebes branch of GP Anshor seemed to distance itself from the manoeuvers of Banser and treat these manoeuvers as not reflective of its organisational policies.

9 Idza Priyanti was selected Second Deputy Chair of the Fatayat NU, Brebes Branch, at the Regional Caucus held at the Dedy Jaya Hotel in Brebes on 27 December 2013. For further detail, see http://brebesnews.co/2013/02/bupati-brebes-satu-satunya-kader-fatayat-nu-dijateng/ 
Considering the material benefits received by NU and the organisations under it, money was the second most prominent consideration in the 2017 election after religion, a fact exacerbated by the fact that Priyanti's opponents Suswono and Mustaqim used a similar strategy. Many informants mentioned that PKS cadres from outside Brebes were mobilised to support Suswono and Mustaqim. Suswono enjoyed some popularity among the people of Brebes, as while he served as Minister of Agriculture he had promoted many programmes to assist farmers, including the distribution of cows to farmers' groups and the provision of subsidised fertiliser/free seeds. The mobilisation of PKS cadres from outside Brebes was supported by the campaign's ability to emphasise economic and social issues in its agenda. Suswono and Mustaqim, for example, skilfully cast doubt on the bureaucracy by protesting the region's damaged road infrastructure, inefficient use of funds, and high poverty rate. As such, religious issues were an important counter agenda for Priyanti's campaign.

Citing the need to debate policy agendas and government programmes, the incumbent played the religion card to challenge her opponents. In this, NU played a central role in delegitimising her opponent's symbolic capital. Both in the open and in closed forums such as prayer groups, NU politicians-through pesantren and tarekat networks-warned voters of the potential danger of electing Suswono and Mustaqim. The opposition candidates were presented as agents for the dissemination of the dangerous concepts of Salafism and Wahhabism, opposed by the NU majority in Brebes.

The widespread dissemination of such rumours, as well as their effect on the candidates' electability, forced Suswono and Mustaqim to declare their support and commitment to accompanying NU's political aspirations. For example, Suswono and Mustaqim openly promised to preserve the practice of Aswaja and related rituals such as tahlil, manaqib, istighotsah, and khaul. In an open letter, the candidates also promised to hold istighotsah every Thursday night at the Brebes Regency pendopo (hall), as well as combat all religious 
understandings incongruent with Aswaja. From this, it is readily apparent that Suswono and Mustaqim were intent on winning the hearts of NU elites and politicians.

More than that, the weakening of patronage politics in the 2017 regional election was related to changes in regulations. As a result of these changes, campaign costs decreased significantly, while increased supervision was intended to prevent money politics. The incidents involving the monitoring committee and Banser was a "blessing in disguise" for the incumbent. In several villages, members of the monitoring committee caught Banser members as they were filling envelopes with 25 thousand rupiah each. Although there were no legal consequences from this report, as a result of this case the 3 milliards meant for Banser was never distributed (personal communication with Wakro, member of the Monitoring Committee, Brebes Regency, 10 January 2017). For the incumbent, this case also served as a reason to not provide promised funding to NU and related organisations, as the reported electoral fraud could have threatened her position.

Regardless of the use of religious issues for political mobilisation, the incumbents' victory in the 2017 regional election was widely predicted, given both their considerable backing from political parties as well as their broad cross-party social networks that they had cultivated both before and during their campaign. Priyanti and Nardjo won the election, receiving $67 \%$ of the votefar more than their opponents, who only received 33\% of the vote. Although this electoral victory involved various factors, the religious issues used by NU clearly contributed to the re-election of Priyanti and Nardjo. The incumbents also benefited from the internal fragmentation within the parties backing their opponents, particularly in Gerindra. ${ }^{10}$ In the lead-up to voting, for example, eleven of Gerindra's seventeen district administrators abandoned

\footnotetext{
10 For more detail, see http://berita.suaramerdeka.com/smcetak/11-pac-gerindra-nyatakandukung-idza-narjo/
} 
their party's candidate and instead supported the incumbents. This movement was initiated by one district administrator with a business interest in selling bus tickets for Dewi Sri, the transportation company owned by the incumbent regent's family.

The 2017 Brebes regional election differed significantly from the 2012 election, where money politics and patronage were the main means of mobilising political support. In the 2012 Brebes regional election, the greatest amount of money was distributed by Priyanti's campaign team. This, combined with fragmentation within NU as well as solid mechanisms within PDIP, allowed Priyanti to emerge victorious in the election. This is not to say religious issues were not involved in the 2012 regional election. Rather, patronage-in the form of the distribution of material resources - was the most prominent means of mobilising support.

Table 4: Candidates and Coalitions in the 2012 Brebes Regional Election

\begin{tabular}{|c|c|c|}
\hline Coalition & Candidates & Supporting Parties \\
\hline Victory & Idza Priyanti \& Nardjo & $\begin{array}{l}\text { PDIP (13 seats) } \\
\text { Gerindra ( } 2 \text { seats }) \\
\text { PKS ( } 5 \text { seats }) \\
\text { P. Demokrat ( } 6 \text { seats) }\end{array}$ \\
\hline Defeat & Agung Widyantoro \& Athoillah Syatori & $\begin{array}{l}\text { Golkar ( } 7 \text { seats) } \\
\text { PKB ( } 7 \text { seats) } \\
\text { PPP (4 seats) } \\
\text { PAN ( } 4 \text { seats) } \\
\text { Hanura ( } 1 \text { seat) }\end{array}$ \\
\hline
\end{tabular}

In the 2012 regional election, Priyanti was reported to have spent billions of rupiah for securing party recommendations, mobilising volunteers, promoting herself in the media, and distributing money to voters. Aside from distributing thousands of rupiah to each voter, Priyanti was reported to have allocated between 800 thousand and 1 million rupiah to donate to the families of deceased voters, especially those in southern Brebes. She was 
reported to have mobilised dozens of her family's buses to provide potential voters with free transportation to tourist destinations (personal communication with Wakro, member of the Monitoring Committee, Brebes Regency, 10 January 2017). This rampant use of money politics proved effective in mobilising political support in the bureaucracy and among the pesantren.

In 2012, PDIP_-facing problems following the resignation of its local leader (Indra Kusuma) as regent-also backed Priyanti. Her victory served not only as a means for PDIP to ensure its continued dominance of local politics in Brebes, but also to exact vengeance upon Golkar, which it considered to have taken an active role in the corruption investigation that led to Kusuma's resignation. PDIP's electoral victory, in the end, also had a positive effect on Kusuma's political career; despite the case against him, he remained trusted with leading the Brebes chapter. The selection of Nardjo as deputy regent was also an important factor for the party backing Priyanti. Nardjo was popular both among the party's administration and among its cadres, both for rising through the ranks and for keeping a low profile. No less important, Nardjo was loyal to his political mentor, the politician and entrepreneur Indra Kusuma.

The internal fragmentation with NU and the different parties backing Widyantoro and Syatori (particularly Golkar) also contributed to Priyanti's 2012 victory. Owing to this fragmentation, Priyanti was capable of gaining the support of Fatayat, one of the women's wings of NU; one of this organisation's leaders was reportedly part of Priyanti's campaign team. The defection of several young members of Golkar to Priyanti also influenced the electoral outcome. Furthermore, Priyanti and Narjo's campaign team was capable of exploiting regional sentiments as an effective means of delegitimising Widyantoro as the incumbent regent; many of the people who lived along the northern coast of Brebes were unwilling to elect Widyantoro owing to his origins in southern Brebes.

This use of religious issues to mobilise support was not able to overcome the widespread use of money politics. Then-incumbent 
Agung Widyantoro (2010-2012), who was running with Athoillah Syatori, the head of the NU branch in Brebes, attempted to use religion as the basis for political mobilisation. The inclusion of PKS in the coalition backing Idza Priyanti and Nardjo was exploited to reduce the candidates' symbolic legitimacy, which was perceived as incongruent with the religious orientation of most Muslims in Brebes. Widyantoro and Syatori utilised their networks with kyai, pesantren, and other Islamic groups to gather political support. However, this proved ineffective in their campaign against Priyanti and -Nardjo.

\section{Conclusion}

As explained above, the involvement of Nahdlatul Ulama (NU) in electoral contestation in Brebes clearly indicates how piety-based political mobilisation has become an integral part of Indonesian electoral politics. As in patronage, symbols and religious values have not weakened, but have become stronger amidst the fierce competition. The most interesting point about the involvement of NU in the contestation of regional elections is not its influence on candidates' victory/defeat. More broadly, the involvement of organisations such as NU allows a more nuanced explanation of local politics in Indonesia, one not limited to the oligarchy, patronclient relations, and questions of institutionalism that have been the focus of academic studies on Indonesian politics since Reformasi.

Based on the case of Brebes, it is apparent that NU is a plural identity with diverse, if not opposite, political interests, as reflected in its fluid and decentralised organisational structure. Furthermore, owing to the plurality of elite interests, as well as the increased focus on rational and autonomous voting at the grassroots level, the organisation's political activities vary across regions and times. Such diverse political behaviours, however, must not always be understood as a sign of weakened authority in members' eyes or increased power brokerage (as suggested by several previous studies) 
(Machmudi, 2011; Fealy and Bush, 2014).

As with other forces of political Islam, NU has faced pressure to moderate its political attitudes and behaviours in the strong political contestations that have emerged in the post-Soeharto era. The organisation is distinguished from other forces of political Islam, such as PKS, because the moderation of its political attitudes and behaviours has not involved the creation of a specific political image or the mobilisation of support using means opposed to their religious principles (Tanuwidjaja, 2010; Tomsa, 2012). Problematically, the interactions between NU, electoral politics, and democracy have not always been fluent (Feillard, 2002). On the one hand, the organisation has had to maintain its distance from practical politics, while on the other hand it has had to preserve its organisational and collective interests. Owing to this dilemma, several NU elites have supported the restoration of indirect elections.

The politicisation and, to a certain extent, commodification of religion is not an ideal basis for mobilising electoral support in a democratic system. The rise of religious conservativism and exploitation by religious elites, as well as politicians and political parties, in electoral contestations in Indonesia offers a worrying glimpse at the future of democracy in Indonesia. The mobilisation of political Islam for electoral benefit may potentially create intolerance and even violence, as recognised by many observers in the 2017 gubernatorial election in Jakarta.

However, the 2017 regional election in Brebes also indicates that piety-based political mobilisation does not always have negative effects (as argued by some). Political Islam cannot simply be understood as a populist response to the dominance of the oligarchy, as argued by Hadiz (2012), or as an indication of continued practice of identity politics (Baswedan, 2004) in Indonesia. The use of piety and religion to mobilise support is but one creative strategy used in fierce electoral competitions. More than that, the development of this phenomenon in Indonesian elections must not necessarily be understood from a normative framework (one of ethical and 
not ethical), but be positioned within the economic and political framework of electoral competition for power. Although this condition is not ideal, and somewhat anomalous, it cannot be separated from the broader economic and political designs of Indonesia's democratic institutions, which have become increasingly liberal. This may be common in political contestations in Indonesia, including both regional and general elections.

Interestingly, the increased prominence of religion in electoral competitions, as well as in general politics, is not unique to Indonesia; it is found in numerous Muslim majority countries in Asia and Africa (See Yavuz, 2003; Liow, 2006; Bayat, 2007). In Turkey and Malaysia, for example, Islamism has been as offering both progressive ideas that can challenge military authoritarianism as well as modern ideas that can overcome political frictions between ethnic groups (Yavus, 2003; Liow, 2006). Unfortunately, the politics of piety as a strategy for political mobilisation in Indonesia has yet to significantly transform the distribution of material resources that has been prominent in Indonesian democracy to date. Rather, electoral contestation has provided an arena in which the oligarchy can manipulate and hijack primordial identities to protect its own interests, something that could potentially prove detrimental to the current democratic system (Hadiz, 2017). 


\section{References}

Aspinall, E. (2013a). A Nation in Fragment: Patronage and Neoliberalism in Contemporary Indonesia. Critical Asian Studies, 45(1), 27-54.

Aspinall, E. (2013b). Popular Agency and Interests in Indonesia's Democratic Transition and Consolidation. Indonesia, 96, 101-121.

Aspinall, E., Dettman, S., \& Warburton, E. (2011). When Religion Trumps Ethnicity: A Regional Election Case Study from Indonesia. South East Asia Research, 19(1), 27-58.

Aspinall, E. and Fealy, G. (2003). Local Power and Politics in Indonesia: Decentralisation and Democratisation. Singapore: ISEAS.

Aspinall, E. and Sukmajati, M. (2016). Electoral Dynamics in Indonesia: Money Politics, Patronage and Clientelism at the Grassroots. Singapore: NUS Press.

Baswedan, A.R. (2004). Political Islam in Indonesia: Present and Future Trajectory. Asian Survey, 44(5), 669-690.

Bayat, A. (2007). Making Islam Democratic: Social Movements and the PostIslamist Turn. Stanford: Stanford University Press.

Buehler, M. (2007). Local Elite Reconfiguration in Post-New Order Indonesia: The 2005 Election of District Government Heads in South Sulawesi. Review of Indonesian and Malaysian Affairs, 41(1), 119-147.

Buehler, M., and Tan, P.J. (2007). Party-Candidate Relationship in Indonesian Local Politics: A Case Study of the 2005 Regional Elections in Gowa, South Sulawesi Province. Indonesia, 84, 41-69.

Bush, R. (2009). Nahdlatul Ulama and the Struggle for Power within Islam and Politics in Indonesia. Singapore: ISEAS.

Choi, N. (2004). Local Elections and Party Politics in Post-Reformasi Indonesia. Contemporary Southeast Asia: A Journal of International and Strategic Studies, 26(2), 280-301.

Choi, N. (2007). Elections, Parties and Elites in Indonesia's Local Politics. South East Asia Research, 15(3), 325-354.

Erb, M., \& Sulistiyanto, P. (2009). Deepening Democracy in Indonesia? Direct Elections for Local Leaders (Pilkada). Singapore: ISEAS.

Fealy, G. (2009). Ijtihad Politik Ulama: Sejarah NU 1952-1967. Yogyakarta: LKiS.

Fealy, G., \& Bush, R. (2014). The Political Decline of Traditional Ulama in Indonesia: The State, Umma and Nahdlatul Ulama. Asian Journal of Social Science, 42(5), 536-560.

Fealy, G., \& White, S. (2008). Expressing Islam: Religious Life and Politics in Indonesia. Singapore: ISEAS.

Feillard, A. (2002). Indonesian Traditionalist Islam's Troubled Experience 
with Democracy (1999-2001). Archipel, 64, 117-144.

Feillard, A. (2009). NU vis a vis Negara: Pencarian Isi, Bentuk dan Makna. Yogyakarta: LKiS.

Ford, M., \& Pepinsky, T.B. (2013). Beyond Oligarchy? Critical Exchanges on Political Power and Material Inequality in Indonesia. Indonesia, 96, 1-9.

Geertz, C. (1960). The Javanese Kijaji: The Changing Role of a Cultural Broker. Comparative Studies in Society and History, 2(2), 228-249.

Hadiz, V.R. (2012). Political Economy and Islamic Politics: Insights from the Indonesian Case. New Political Economy, 17(2). 137-155. - (2017). The Indonesian Oligarchy's Islamic Turn?. http:// www.internationalaffairs.org.au/australianoutlook/indonesianoligarchys-islamic-turn/

Hadiz, V.R., \& Robison, R. (2013). The Political Economy of Oligarchy and the Reorganization of Power in Indonesia. Indonesia, 96, 3557.

Hadiz, V.R., \& Teik, K.B. (2011). Approaching Islam and Politics from Political Economy: A Comparative Study of Indonesia and Malaysia. The Pacific Review, 24(4), 463-485.

Laode, I. (1996). Anatomi Konflik: NU, Elit Islam, dan Negara. Jakarta: Pustaka Sinar Harapan.

Liow, J.C. (2006). Piety and Politics: Islamism in Contemporary Malaysia. New York: Oxford University Press.

Jung, E. (2014). Islamic Organizations and Electoral Politics in Indonesia: The Case of Muhammadiyah. South East Asia Research, 22(1), 7386.

Liddle, R.W., \& Mujani, S. (2007). Leadership, Party and Religion: Explaining Voting Behavior in Indonesia. Comparative Political Studies, 40(7), 832-857.

Machmudi, Y. (2011). The Decline of Ulama Authority in Indonesia: The Cases of Two Pesantrens in East Java (Pesantren Langitan Tuban and Pesantren Darul Ulum Jombang). In International Workshop on Muslim Religious Authority in Asia. Singapore: Asia Research Institute, National University of Singapore.

Ramage, D.E. (1995). Politics in Indonesia: Democracy, Islam and the Ideology of Tolerance. London and New York: Routledge.

Robison, R., \& Hadiz, V.R. (2004). Reorganising Power in Indonesia: The Politics of Oligarchy in an Age of Markets. London: Curzon Routledge.

Sebastian, L.C. (2004). The Paradox of Indonesian Democracy. Contemporary Southeast Asia: A Journal of International and Strategic Studies, 26(2), 256-279.

Tan, P.J. (2006). Indonesia Seven Years After Soeharto: Party System 
Institutionalization in a New Democracy. Contemporary Southeast Asia: A Journal of International and Strategic Studies, 28(1), 88-114.

Tanuwidjaja, S. (2010). Political Islam and Islamic Parties in Indonesia: Critically Assessing the Evidence of Islam's Political Decline. Contemporary Southeast Asia: A Journal of International and Strategic Studies, 32(1), 29-49.

Tomsa, D. (2012). Moderating Islamism in Indonesia: Tracing Patterns of Party Change in the Prosperous Justice Party. Political Research Quarterly, 65(3), 486-498.

Turmudi, E. (2007). Struggling for the Umma: Changing Leadership Roles of Kiai in Jombang, East Java. Canberra: ANU Press.

Ufen, A. (2008). From Aliran to Dealignment: Political Parties in PostSoeharto Indonesia. South East Asia Research, 16(1), 5-41.

Vel, J. (2005). Pilkada in East Sumba: An Old Rivalry in a New Democratic Setting. Indonesia, 80, 80-107.

Winters, J.A. (2013). Oligarchy and Democracy in Indonesia. Indonesia, 96, 11-33.

Yavuz, M.H. (2003). Islamic Political Identity in Turkey. New York: Oxford University Press.

These abbreviations should be understood as follows

PDIP : Partai Demokrat Indonesia-Perjuangan / Democratic Party of Indonesia-Struggle

P. Golkar : : Partai Golongan Karya / Working Groups Party

PKB : Partai Kebangkitan Bangsa / National Awakening Party

PAN : Partai Amanat Nasional / National Mandate Party

PPP : Partai Persatuan Pembangunan / United Development Party

PKS : Partai Keadilan Sejahtera / Prosperous Justice Party

P. Demokrat : Partai Demokrat / Democratic Party

P. Gerindra : Partai Gerakan Indonesia Raya / Great Indonesia Movement Party

Hanura : Partai Hati Nurani Rakyat / People's Conscience Party 